\title{
Obesity and COVID-19 infection severity: from pathophysiology to clinical implications
}

\author{
Abdallah FAYSSOIL (1, 2), MD, Marie Charlotte De Carne De Carnavalet (3), MD Nicolas \\ MANSENCAL (2,4), MD, PhD Frédéric LOFASO (5), MD, PhD, Benjamin DAVIDO (6), MD, MS
}

1) Service de cardiologie, Hôpital Raymond Poincaré, APHP, Garches, France

2) Service de cardiologie, Centre de référence des cardiomyopathies et des troubles du rythme cardiaque héréditaires ou rares, Hôpital Ambroise Paré, AP-HP, Université Paris Saclay/UFR Simone Veil-SantéUniversité de Versailles Saint Quentin en Yvelines, Boulogne-Billancourt, France

3) Services de Maladies Infectieuses Centre Hospitalier Mignot, Versailles, France

4) INSERM U-1018, CESP, Clinical Epidemiology, UVSQ, Villejuif, France

5) Service de Physiologie - Explorations fonctionnelles, Hôpital Raymond Poincaré, APHP, Université Paris Saclay/UFR Simone Veil-Santé -Université de Versailles Saint Quentin en Yvelines, Garches, France

6) Service de maladies infectieuses, Hôpital Raymond Poincaré, APHP, AP-HP, Université Paris Saclay/UFR Simone Veil-Santé-Université de Versailles Saint Quentin en Yvelines, Garches, France

Corresponding author:

Abdallah FAYSSOIL, MD

Raymond Poincaré Hospital, APHP, Garches, France

E-mail: abdallah.fayssoil@aphp.fr

\begin{abstract}
Obesity is a significant public health concern with higher morbidity. Obesity patients are at risk of severe COVID-19 infection and obesity is a higher risk factor for intensive Care Unit admission in COVID-19 infection. Obesity status affects lung volumes, cardiac structure and hemodynamics. Obesity is associated with a low inflammation state, endothelial dysfunction, hyperinsulinaemia and metabolic disorders. The authors review cardio-respiratory pathophysiological aspects involved in obesity and propose clinical management in obese patients infected by COVD-19.
\end{abstract}

Key Words: COVID-19; Obesity; BMI; heart; lung; severity

Word count: 2601 


\section{Introduction}

Obesity, defined by a body mass index (BMI) $\geq 30 \mathrm{~kg} / \mathrm{m}^{2}$, is a significant public health problem with higher morbidity and mortality (1). Obesity is also associated with early mortality $(2,3)$. Obesity affects not only adults but also adolescents with a prevalence estimated at $17 \%$ in childhood including adolescents in the USA (4). Moreover, the prevalence of obesity reaches up to $35 \%$ in adults (5). Obesity is associated with cardiovascular risk factors and events $(6,7)$. In parallel, obesity affects the respiratory system with a reduction of lung capacity and compliance (8). Obesity patients with COVID-19 are at higher risk of severe COVID-19 form and obesity is a higher risk factor for intensive care unit (ICU) admission $(9,10)$. In France, the prevalence of obesity reaches $25 \%$ in patients with severe COVID-19 (11), while the prevalence in the global population is estimated about $17 \%$ (12). In a study conducted in Michigan concerning 463 COVID-19 patients (39.7\% required ICU admission), up to $58 \%$ of patients were obese (13). In another study in New York City, 46\% of ICU patients with COVID-19 were obese (14). In ICU, severe COVID-19 is associated with higher mortality in obese patients $(13,15)$. Moreover, a severe obesity defined by a $\mathrm{BMI} \geq 35 \mathrm{~kg} / \mathrm{m}^{2}$, was associated with ICU admission (OR=5.39) in a recent study conducted in the United States (16). Finally, obesity status may affect the renin angiotensin system and obesity is associated with endothelial dysfunction, hyperinsulinaemia and a low inflammation state $(17,18)$.

We aim to review the cardio-respiratory pathophysiological aspects involved in obesity and to propose clarifications in the clinical management of obese patients suffering from COVID19 infection.

\section{Heart and obesity}

Obesity may induce diabetes mellitus, hypertension, insulin resistance and dyslipidemia, leading to an increased risk of cardiovascular disease (19). In addition, metabolic disorders are frequent in obesity and are associated with coronary microvascular impairment with a reduced coronary flow reserve, particularly in patients with diabetes and lipid profile abnormality (20). Patients with cardiovascular risk factors are at risk of severe COVID-19 infection with myocardial injury, acute coronary syndrome, arrhythmia, heart failure and microvascular thrombosis $(21,22$, and 23). In addition, patients with COVID-19 infection may have alteration of the left ventricle and the right ventricle (24). Pulmonary hypertension may also be present in the context of COVID-19 infection (25). Myocardial abnormalities can be present, even after COVID-19 infection recovery, as previously shown (26, 27, and 28). Mechanisms involved in the onset of myocardial injury in the context of COVID-19 infection, are multiple and include hypoxemia, cytokines storm, microvascular thrombi, coronary plaque instability, systemic and vessels inflammation, myocarditis, sepsis related cardiomyopathy, stress-related cardiomyopathy and arrhythmia $(29,30,31,32)$.

In the context of COVID-19 outbreak, clinical severity might be partially attributable to the underlying myocardial abnormalities in obese patients. From a mechanical point of view, obesity affects the left ventricular (LV) structure and function with the presence of subclinical myocardial impairments $(33,34)$. In fact, adaptive mechanisms occur in obese patients with an increase of several cardiac parameters: LV mass, stroke volume, cardiac output, and total and central blood volume $(35,36,37)$. This hemodynamic changes may 
lead to LV dilation and to the onset of eccentric LV hypertrophy $(36,37)$ (figure 1). In the multiethnic cohort study, obesity was found to be associated with LV concentric remodeling and Turkbey et al (34) found a positive association between an index of LV geometry (LV mass-to-LV end diastolic volume ) and BMI. In fact, BMI is associated with LV tissue Doppler imaging velocities and global longitudinal strain features $(33,38)$. Diastolic function is also affected in patients with obesity with abnormal tissue Doppler velocities and decreased longitudinal strain $(33,38$, and 39). Prevalence of diastolic dysfunction may reach $19 \%$ in obese patients (40). Furthermore, obesity affects left atrial (LA) size, LA reservoir and conduit (41) with a significant correlation between LA size and LV mass (42). In this context, obesity increases the risk of heart failure and the risk of atrial fibrillation $(43,44)$. In a longterm follow-up study (>20 years), that included 15,402 individuals, obesity was found to be significantly associated with cardiovascular hospital admissions and cardiovascular deaths (45). Right heart hemodynamics may also be impaired in severe obese state with an increased right atrial and pulmonary pressure (46). Obesity is also a risk factor for venous thromboembolism (47). Inversely, weight loss is associated with positive cardiac effects that included improvement of cardiac systolic and diastolic function and reductions of LV mass, of stroke volume, of filling pressures and of resting oxygen consumption $(48,49)$. 


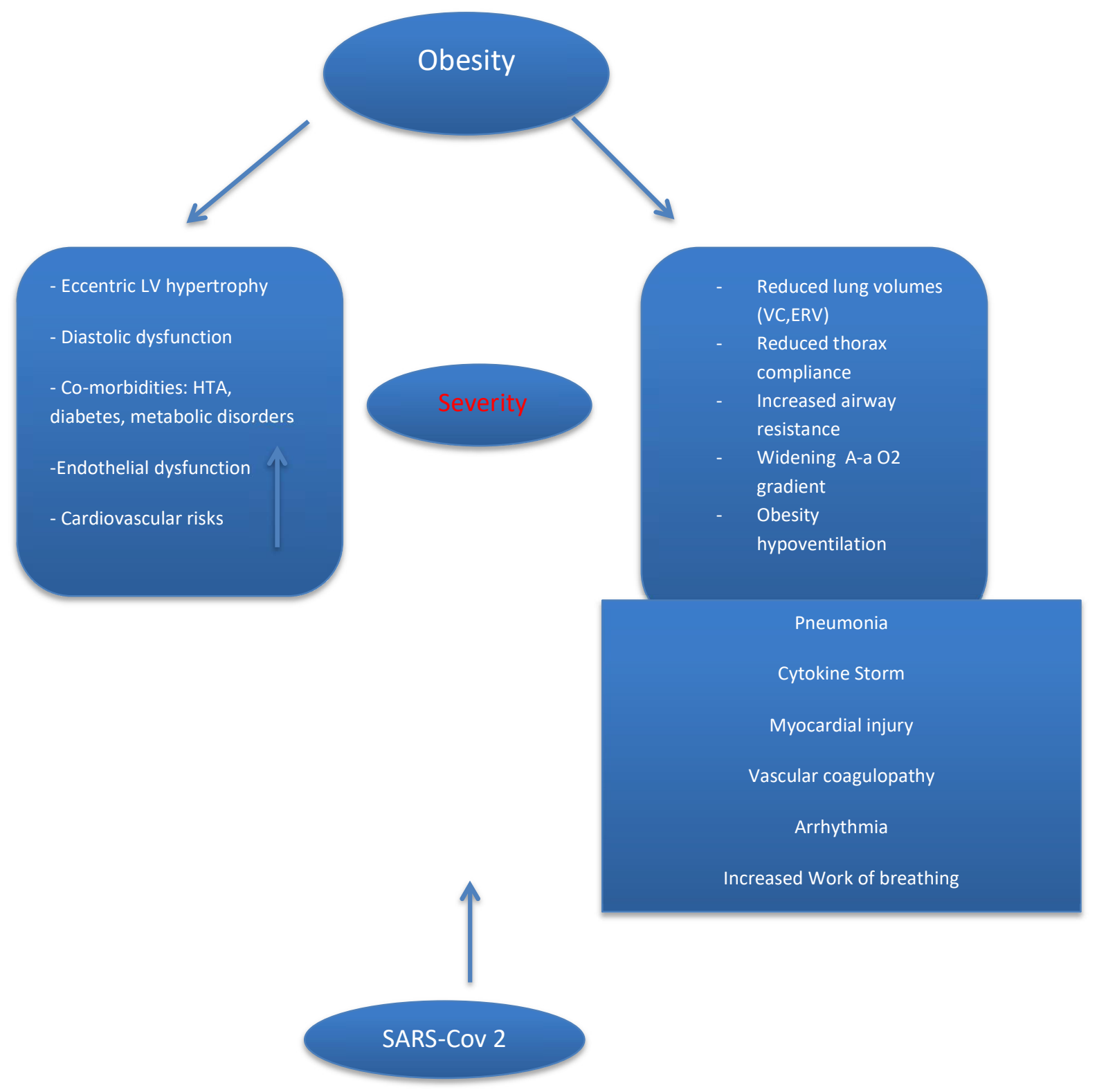

Figure 1: pathophysiological aspects in obese patients

HTA: hypertension; VC: vital capacity; ERV: expiratory reserve volume

Finally, abdominal obesity may have a high accuracy for predicting cardiac features rather than general obesity (50). In fact, an increase of abdominal obesity is associated with LV global longitudinal strain abnormalities and heart failure $(39,51)$. Abdominal obesity is frequently associated with dyslipidemia, low high-density lipoprotein cholesterol, increased triglycerides, apo lipoproteins B levels, insulin resistance, atherogenic abnormalities and abdominal adiposity is associated with cardiovascular disease (52). The figure 1 summarizes pathophysiological aspect involved in obesity and covid-19. 


\section{Lung function and Obesity}

COVID-19 infection affects particularly the lung with severe pneumonia and sometimes onset of acute respiratory distress syndrome $(\operatorname{ARDS})(21,23)$. The presence of heart failure, diabetes, a BMI>40 kg/m² and aging are factors associates with critical illness severity (15). SARS-CoV-2 has a high affinity for the lung via the ACE2 receptor present in respiratory epithelial cells (53). One can assume that the underlying lung function status may worsen clinical status in the context of obesity because of a decrease of lung compliance, a decrease of chest wall compliance (54) and the recumbency position worsen the respiratory compliance (55). In fact, in supine position, the reduction of the expiratory reserve volume (ERV) worsens, due to the ascending of the diaphragm within the thorax and causes a length-tension disadvantage for the diaphragm due to fibre overstretching (56).

Patients with obesity disclosed lower lung volumes that include reductions of forced vital capacity (VC), of forced expiratory volume in one second (FEV1), and of expiratory reserve volume (ERV) (8) (figure 1). This is associated with an increase of airway resistance and an impairment of the upper airway mechanics $(56,57)$. Obese patients have to overcome this previous airway increase. Inspiratory time is also decreased with an increase of the respiratory rate $(56,58)$. Abdominal obesity is also associated with lung volume reduction with a negative association between forced vital capacity (FVC) and abdominal adiposity (59, 60).

In obese patients, the work of breathing is increased (57) and the diaphragm motion is impeded by the abdomen adipose tissue. The expiratory flow limitation leads to a dynamic hyperinflation, creating an auto-PEEP, in relation with the incomplete expiration $(61,62)$. Also, the strength of respiratory muscles is affected in obesity $(63,64)$. Finally, in the context of obesity, lung bases are under-ventilated but over-perfused, creating a ventilationperfusion mismatch (65). In addition, obesity may be associated with a mild widening of the A-aO2 gradient $(66,67)$. Hypoxemia and A-a 02 gradient are correlated with ERV $(56)$.

Obesity is also a risk factor for obstructive sleep apnea and obesity hypoventilation syndrome is frequent (68). Obstructive sleep apnea can cause cardiovascular features that include hypertension, endothelial dysfunction, metabolic disorders, arrhythmia and cardiac remodeling (69). Obesity hypoventilation syndrome (OHS) is defined by an increase of daytime $\mathrm{PaCO} 2>45 \mathrm{mmHg}$, associated with sleep-related breathing disorders in patients with $\mathrm{BMI} \geq 30 \mathrm{~kg} / \mathrm{m}^{2}$, in the absence of known causes of hypoventilation (68). The prevalence of OHS has been reported to range between $8 \%$ and $20 \%$ in obese patients and the prevalence of hypertension reaches $55 \%$ to $88 \%$ (70). Other comorbidities associated with OHS are metabolic derangement, coronary artery disease and heart failure (70). One can assume that the presence of these previous comorbidities may worsen clinical status in obese patents in a context of COVID-19 infection.

\section{Obesity, inflammation, Angiotensin 1-7 and COVID-19}

Hyperinsulinaemia and endothelial dysfunction, frequent in obese patients, may lead to an activation of the renin angiotensin aldosterone system (RAAS) (17). This RAAS plays a key role in humans, controlling blood pressure, electrolyte balance and cardiac remodeling. The COVID-19 infects the host via ACE2 receptors that are membrane-bound amino peptidases receptors, present in many organs that include lung, heart, kidney, endothelial cells, and gut. 
Adipose tissue expresses also ACE2 that catalyzes the conversion of angiotensin 2 to angiotensin (1-7), that displays an opposition to pro-inflammatory, vaso-constrictive and pro-atherosclerotic properties of angiotensin-2 (figure 2) $(71,72)$. These properties involve the ACE2/ang-(1-7)/MAS axis, MAS being a G protein-coupled receptor for angiotensin (1-7) (figure 2). Dysfunction of MAS can lead to endothelial dysfunction, hypertension, thrombosis and metabolic syndrome like state (73). In the context of COVID-19 infection, angiotensin (17) production can decrease in patients, contribution to clinical severity (74).

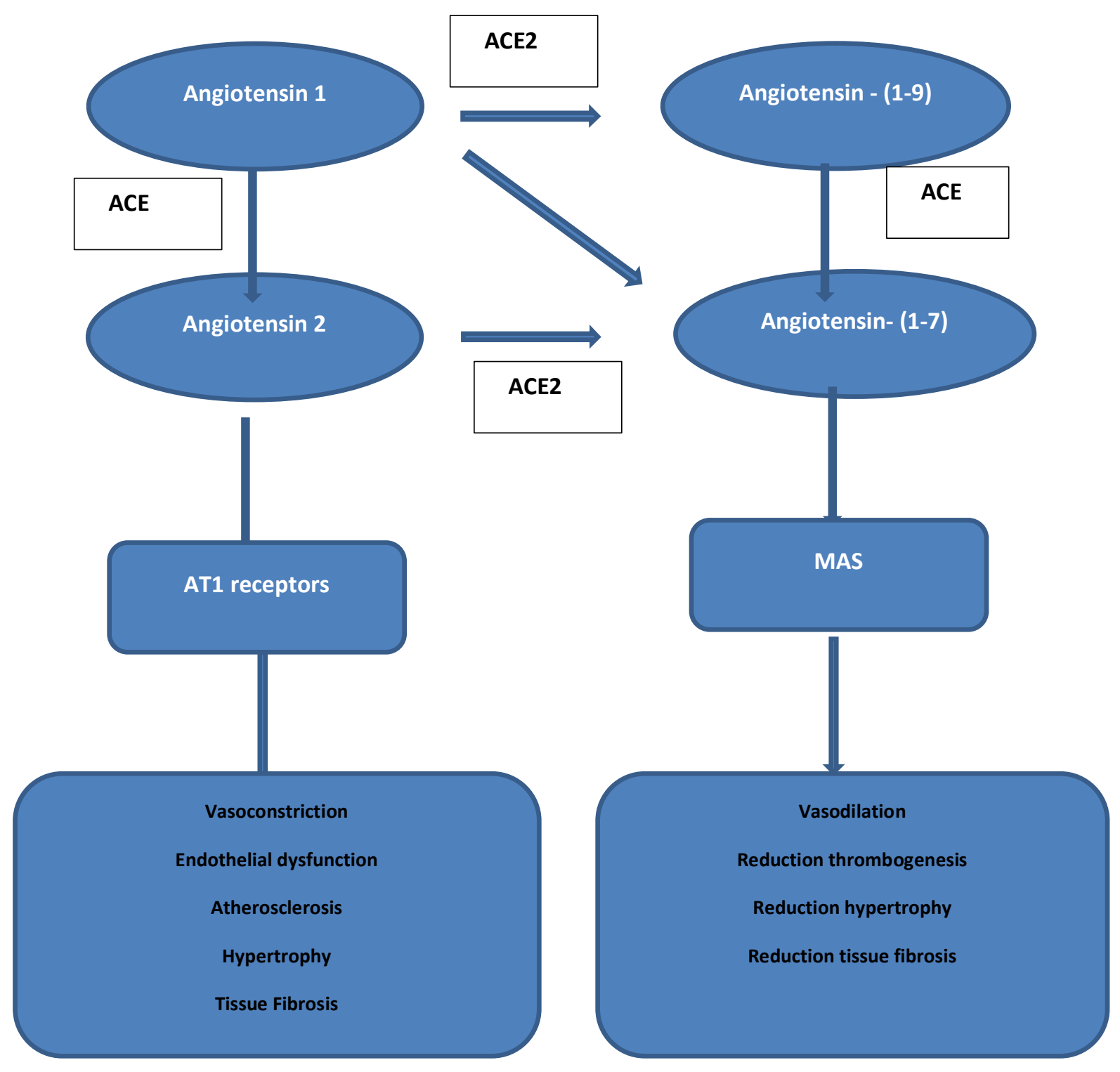

Figure 2: Renin angiotensin system and angiotensin-(1-7)/Mas axis

ACE2: angiotensin converting enzyme type 2 
Adipose tissue may play also a role in in COVID-19 infection. In fact, adipocytes seem to be significant targets for SARS-CoV-2 entry via ACE2 receptors and might play a role as a viral reservoir $(75,76$, and 77$)$. In addition, adipokines, secreted by adipocytes, may interplay in the inflammatory pathway and in metabolism in the context of obesity. Adipokine and interleukin 6 (IL6) are increased in obesity (78). Leptin, involved in food intake, is increased in obese patients (79), whereas adiponectin is reduced. Insulin resistance, which can be assessed by the ratio leptin/adiponectin, might be a potential link between covid-19 infection and clinical severity in obese patients (80). In addition, immunological system is over activated with an inflammatory state and a cytokine release syndrome in COVID-19 patients (18). In fact, patients with COVID 19 display a high level of IL6, significantly associated with disease severity (81). Deceased patients with COVID-19 disclosed higher concentrations of IL6, interleukin 8, interleukin 10 and tumor necrosis factor (TNF) alpha (82). Finally, a low-grade chronic inflammation is present in obese patients, in relation with adipose tissue dysfunction (83). In the context of COVID-19 infection, an exaggerated adipose tissue lipolysis may occur, in response to the production of pro-inflammatory cytokines (83).

\section{Clinical implications in the management of obese COVID- 19 patients}

In addition with classical tools used to stratify patients (CURB-69), BMI should be mentioned in the managements of COVID-19 pneumonia patients. Cardiorespiratory monitoring should be mandatory.

Regarding the respiratory system, it may be useful to avoid supine position. In the context of COVID-19 infection, an imbalance between the demand on the respiratory muscles and their capacity to generate tension may worsen respiratory symptoms in obese patients (84). In addition, since the rest gradient $\mathrm{A}-\mathrm{a} \mathrm{O} 2$ is mild widening and because the gradient $\mathrm{A}-\mathrm{a} \mathrm{O} 2$ is associated with pneumonia severity (85), one may expect that obese COVID patients experienced severe gradient A-a O2. Furthermore, the onset of thrombo-embolism events can be higher on obese patients with COVID-19 since obesity state and COVID-19 are two risk factors for thromboembolic events $(86,87)$. In this context, anticoagulation should be used particularly in obese patients to avoid thrombo-embolic events.

Regarding the cardiac system, cardiac comorbidities are often present in obese patients. One should focus on cardiac function, particularly the diastolic function in the context of COVID19 pneumonia. Global longitudinal strain can be affected in COVID-19 infected patients (figure 3).Risk factors associated with diastolic dysfunction are classically age, hypertension, obesity, coronary disease, and arrhythmia and kidney disease (88). Cardiac biomarkers and electrocardiogram should be performed and monitored to stratify patients and to search for eventual cardiovascular complications $(32,89,90)$, since these parameters affects prognosis $(21,22)$. Echocardiography that must be performed with health worker protection's measures can help to stratify patients focusing on LV geometric, LV function, diastolic function, RV function and pulmonary pressures. 


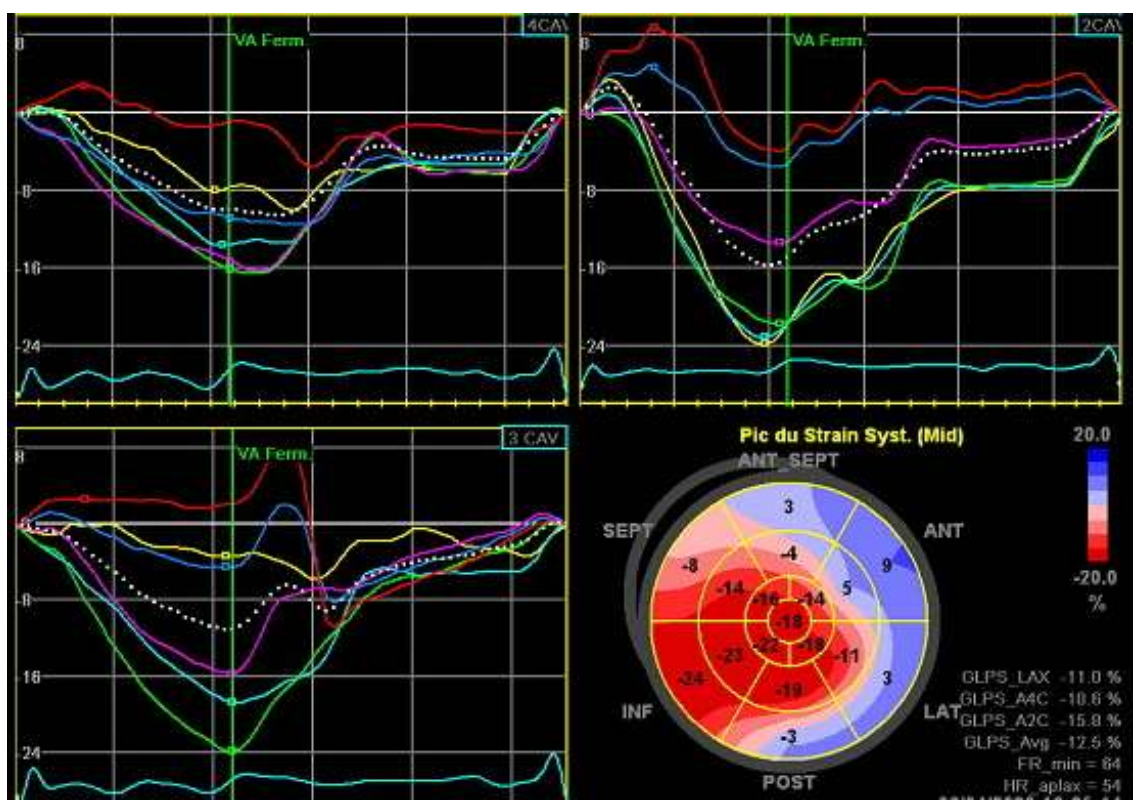

Figure 3: 2D strain echocardiography in a COVID-19 patient

Note the reduced left ventricular global longitudinal strain

In critically ill obese patients, difficulties in the airway management during the inductionintubation phase must be anticipated. Regarding ventilation setting, tidal volume should be adapted using the predicted body weight (91). These patients are at high risk of atelectasis during anesthesia in supine position (92). In fact, during anesthesia, in supine position, the large abdominal adipose tissue leads to a cranial displacement of the diaphragm that can contributes to the onset of atelectasis (92). Positive end expiratory pressure (PEEP), that prevents atelectasis and that is also used in patients on ARDS, should be adapted, since PEEP can cause hemodynamic impairment, right ventricle dysfunction (figure 4) and can impede venous return (93).

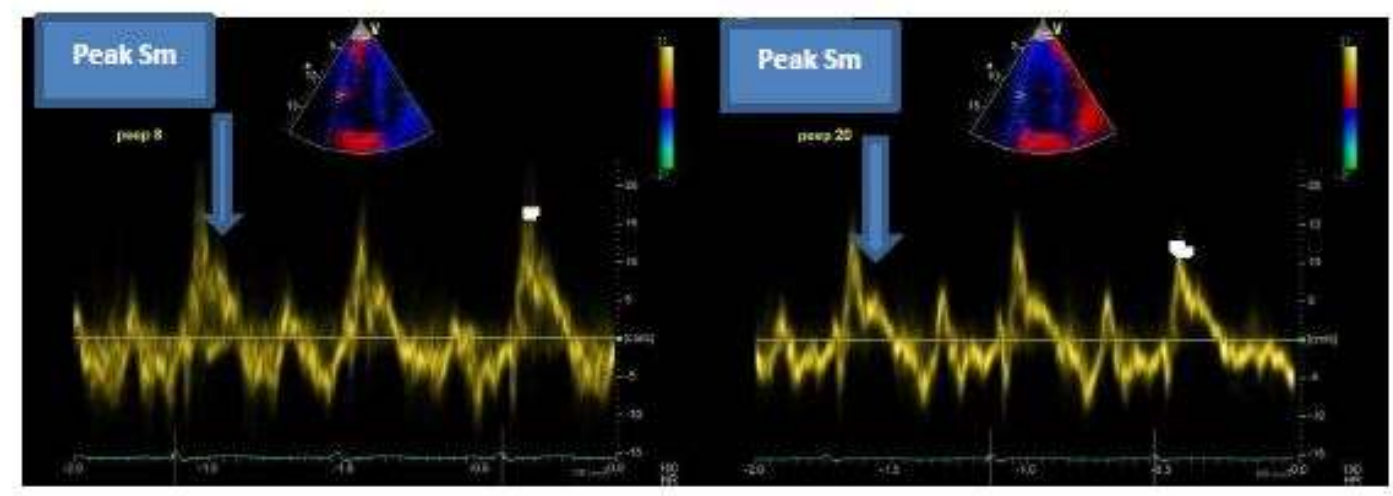

Figure 4: Right ventricular function analysis using Tissue Doppler imaging (Doppler-Echocardiography) in a COVID-19 ARDS patient on mechanical ventilation

Note the significant reduction of the peak right ventricle peak Sm velocity, depending on PEEP level (from PEEP $8 \mathrm{cmH} 20$ to PEEP $20 \mathrm{cmH20}$ ); ARDS: Acute respiratory distress syndrome; PEEP: positive end expiratory pressure 
Monitoring plateau pressure and driving pressure is crucial, in addition with the search for the presence of intrinsic PEEP in patients on mechanical ventilation (91). In fact, during mechanical ventilation, monitoring trans-pulmonary pressure, that is the difference between alveolar pressure and pleural pressure, can be useful to adapt ventilation setting and to avoid lung collapse (92).

Patients with severe ARDS experienced long ICU length of stay. This parameter is known to affect diaphragm function and mass (94). Since respiratory muscles inspiratory strength may be affected in obese patients, one may expect to have severe diaphragm function dysfunction in obese COVID-19 and a longer ICU length of stay. Diaphragm ultrasound can be used to assess and follow diaphragm function in this context (figure 5). Diaphragm dysfunction is a classical cause of respiratory related weaning failure. This diaphragm dysfunction can be evaluated using ultrasound by measuring diaphragm thickening and/or diaphragm motion during a spontaneous breathing trial (figure) $(95,96)$.

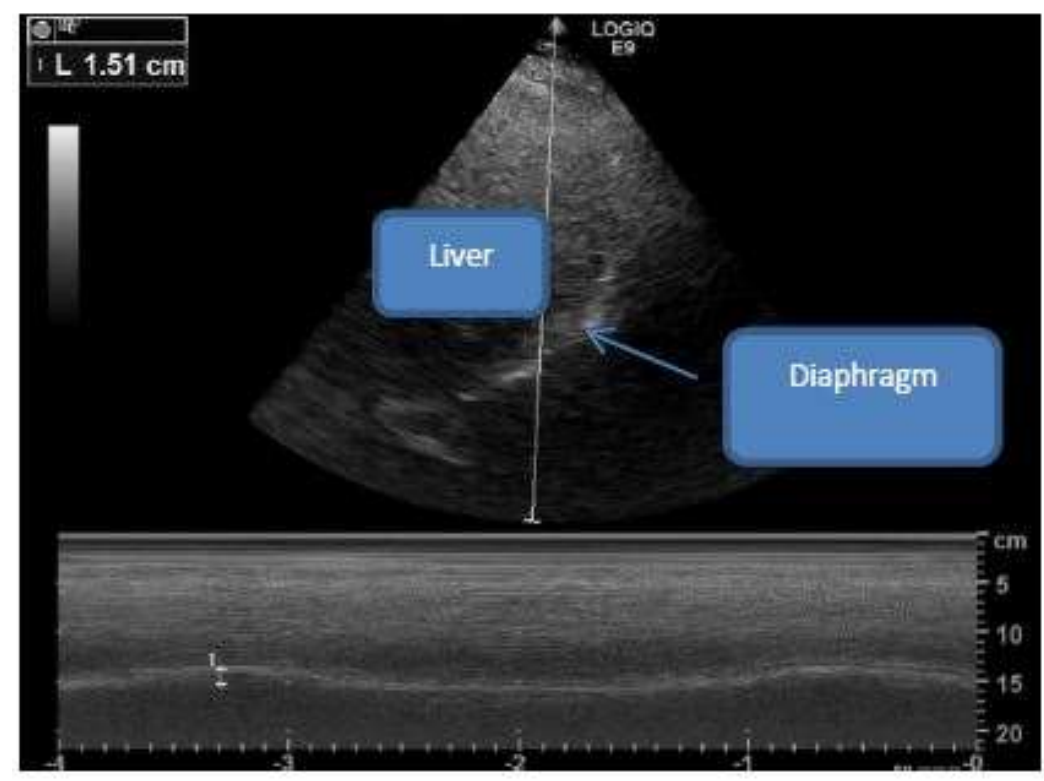

Figure 5: Right diaphragmatic motion using ultrasound in COVID - 19 patient with obesity

Physicians must be vigilant in this population during weaning process. In fact, weaning failure is associated with an increase of morbidity, nosocomial pneumonia, severity outcomes and mortality $(97,98)$. Weaning failure may be due to heart failure, respiratory muscle weakness, and sepsis. Echocardiography should be done, searching for left ventricular impairment, left ventricular diastolic dysfunction, combined to diaphragm ultrasound $(99,100)$.

Diastolic dysfunction is relatively frequent in critically ill patients, in the context of sepsis and myocardial ischemia $(101,102)$. Diastolic dysfunction is a classical cause of weaning failure in ICU patients $(103,104)$. Liu et al $(105)$ reported an incidence of weaning failure reaching $45 \%$ (among them, 59\% of weaning-induced pulmonary edema). Risk factors of weaning induced pulmonary edema are obesity, previous cardiopathy and COPD (105). 
In fact, during the weaning process, the shift from mechanical ventilation to spontaneous breathing induces a negative intra thoracic pressure that can affect cardiac function (95, 106). This negative intra-thoracic pressure caused by the transition from mechanical ventilation to spontaneous breathing, increases venous return, left ventricular afterload and may cause ischemia, as reported initially by Lemaire et al (107). In addition, adrenergic tone increases during spontaneous breathing trial (107) and myocardial oxygen demand increases (108). Physicians should be careful in the context of COVID, since myocardial ischemia and myocardial injury are frequent in critically ill COVID-19 patients (109) and myocardial ischemia can occur during weaning process in ICU patients (110). Plasma BNP level and plasma BNP variation during a spontaneous breathing trial can be used to predict weaning failure (111). Finally, COPD can be associated with obesity (112). COPD patients are at risk of weaning failure. In fact, in COPD, a high negative intra-thoracic pressure is necessary to generate tidal volume, since COPD is associated with airway obstruction. During weaning trail, this phenomenon increases the work of breathing, the venous return, the LV afterload and can induce RV dilation by an increase of RV afterload (112). All these previous pathophysiological aspects may explain the relative higher critically illness in ICU obese patients.

\section{Conclusion}

Obesity is acknowledged to be a factor of severe COVID-19 presentation, which requires attention by physicians in case of respiratory presentation. ICU physicians must be wary of the necessity of surveillance in the weaning process after intubation, because of a reduced muscle functionality and capacity. Cardiologists must be vigilant about the potential diastolic and systolic left ventricular dysfunction particularly in patients with cardiovascular risk factors and co morbidities.

\section{Compliance with Ethical Standards:}

Funding: this study has no funding

\section{Conflict of Interest:}

AF declares that he has no conflict of interest

MCDC declares that he has no conflict of interest

NM declares that he has no conflict of interest

FL declares that he has no conflict of interest

BD declares that he has no conflict of interest

Ethical approval: All procedures performed in studies involving human participants were in accordance with the ethical standards of the institutional and/or national research committee and with the 1964 Helsinki declaration and its later amendments or comparable ethical standards

Informed consent : not applicable 


\section{References}

1) Flegal KM, Kit BK, Orpana H, Graubard BI. Association of all-cause mortality with overweight and obesity using standard body mass index categories: a systematic review and meta-analysis.JAMA. 2013 Jan 2;309(1):7182.

2) Flegal KM, Graubard BI, Williamson DF, Gail MH. Excess deaths associated with underweight, overweight, and obesity.JAMA. 2005 Apr 20;293(15):1861-7

3) Greenberg JA. Obesity and early mortality in the United States. Obesity (Silver Spring). 2013 Feb;21(2):40512

4) Ogden CL, Carroll MD, Lawman HG, Fryar CD, Kruszon-Moran D, Kit BK, Flegal KM. Trends in Obesity Prevalence Among Children and Adolescents in the United States, 1988-1994 Through 2013-2014.JAMA. 2016 Jun 7;315(21):2292-9.

5) Ogden CL, Carroll MD, Kit BK, Flegal KM. Prevalence of childhood and adult obesity in the United States, 2011-2012.JAMA. 2014 Feb 26;311(8):806-14.

6) Wilson PW, D'Agostino RB, Sullivan L, Parise H, Kannel WB. Overweight and obesity as determinants of cardiovascular risk: the Framingham experience. Arch Intern Med. 2002 Sep 9;162(16):1867-72

7) Levitan EB, Yang AZ, Wolk A, Mittleman MA. Adiposity and incidence of heart failure hospitalization and mortality: a population-based prospective study.Circ Heart Fail. 2009 May;2(3):202-8.

8) Lazarus R, Sparrow D, Weiss ST. Effects of obesity and fat distribution on ventilatory function: the normative aging study.Chest. $1997 \mathrm{Apr} ; 111(4): 891-8$

9) Gao F, Zheng KI, Wang XB, Sun QF, Pan KH, Wang TY, Chen YP, Targher G, Byrne CD, George J, Zheng MH. Obesity Is a Risk Factor for Greater COVID-19 Severity. Diabetes Care. 2020 Jul;43(7):e72-e74

10) Simonnet A, Chetboun M, Poissy J, Raverdy V, Noulette J, Duhamel A, Labreuche J, Mathieu D, Pattou F, Jourdain M; LICORN and the Lille COVID-19 and Obesity study group. High Prevalence of Obesity in Severe Acute Respiratory Syndrome Coronavirus-2 (SARS-CoV-2) Requiring Invasive Mechanical Ventilation.Obesity (Silver Spring). 2020 Jul;28(7):1195-1199.

11) Caussy C, Pattou F, Wallet F, Simon C, Chalopin S, Telliam C, Mathieu D, Subtil F, Frobert E, Alligier M, Delaunay D, Vanhems P, Laville M, Jourdain M, Disse E; COVID Outcomes HCL Consortium and Lille COVIDObesity Study Group. Prevalence of obesity among adult inpatients with COVID-19 in France.Lancet Diabetes Endocrinol. $2020 \mathrm{Jul} ; 8(7): 562-564$

12) https://www.santepubliquefrance.fr/les-actualites/2017/etude-esteban-2014-2016-chapitre-corpulencestabilisation-du-surpoids-et-de-I-obesite-chez-I-enfant-et-l-adulte

13) Suleyman G, Fadel RA, Malette KM, Hammond C, Abdulla H, Entz A, Demertzis Z, Hanna Z, Failla A, Dagher C, Chaudhry Z, Vahia A, Abreu Lanfranco O, Ramesh M, Zervos MJ, Alangaden G, Miller J, Brar I. Clinical Characteristics and Morbidity Associated With Coronavirus Disease 2019 in a Series of Patients in Metropolitan Detroit. JAMA Netw Open. 2020 Jun 1;3(6):e2012270.

14) Argenziano MG, Bruce SL, Slater CL, Tiao JR, Baldwin MR, Barr RG, Chang BP, Chau KH, Choi JJ, Gavin N, Goyal P, Mills AM, Patel AA, Romney MS, Safford MM, Schluger NW, Sengupta S, Sobieszczyk ME, Zucker JE, Asadourian PA, Bell FM, Boyd R, Cohen MF, Colquhoun MI, Colville LA, de Jonge JH, Dershowitz LB, Dey SA, Eiseman KA, Girvin ZP, Goni DT, Harb AA, Herzik N, Householder S, Karaaslan LE, Lee H, Lieberman E, Ling A, Lu R, Shou AY, Sisti AC, Snow ZE, Sperring CP, Xiong Y, Zhou HW, Natarajan K, Hripcsak G, Chen R. Characterization and clinical course of 1000 patients with coronavirus disease 2019 in New York: retrospective case series.BMJ. 2020 May 29;369:m1996 
15) Petrilli CM, Jones SA, Yang J, Rajagopalan H, O'Donnell L, Chernyak Y, Tobin KA, Cerfolio RJ, Francois F, Horwitz LI. Factors associated with hospital admission and critical illness among 5279 people with coronavirus disease 2019 in New York City: prospective cohort study.BMJ. 2020 May 22;369:m1966

16) Kalligeros M, et al. Association of Obesity with Disease Severity Among Patients with Coronavirus Disease 2019. Obesity (Silver Spring). 2020

17) Schütten MT, Houben AJ, de Leeuw PW, Stehouwer CD. The Link Between Adipose Tissue ReninAngiotensin-Aldosterone System Signaling and Obesity-Associated Hypertension.Physiology (Bethesda). 2017 May;32(3):197-209

18) Vaninov N. In the eye of the COVID-19 cytokine storm. Nat Rev Immunol. 2020 Apr 6

19) Poirier $P$, Lemieux I, Mauriège $P$, Dewailly $E$, Blanchet $C$, Bergeron J, Després JP. Impact of waist circumference on the relationship between blood pressure and insulin: the Quebec Health Survey.Hypertension. 2005 Mar;45(3):363-7.

20) Kosmala W, Sanders P, Marwick TH. Subclinical Myocardial Impairment in Metabolic Diseases. JACC Cardiovasc Imaging. 2017 Jun;10(6):692-703.

21) Wang D, Hu B, Hu C, Zhu F, Liu X, Zhang J, Wang B, Xiang H, Cheng Z, Xiong Y, Zhao Y, Li Y, Wang X, Peng Z. Clinical Characteristics of 138 Hospitalized Patients With 2019 Novel Coronavirus-Infected Pneumonia in Wuhan, China. JAMA 2020; 323:1061-1069

22) Guo T, Fan Y, Chen M, Wu X, Zhang L, He T, Wang H, Wan J, Wang X, Lu Z.Guo T, et al. Cardiovascular Implications of Fatal Outcomes of Patients With Coronavirus Disease 2019 (COVID-19). JAMA Cardiol 2020 Mar 27;e201017. doi: 10.1001/jamacardio.2020.1017.

23) Yang X, Yu Y, Xu J, Shu H, Xia J, Liu H, Wu Y, Zhang L, Yu Z, Fang M, Yu T, Wang Y, Pan S, Zou X, Yuan S, Shang Y. Clinical course and outcomes of critically ill patients with SARS-CoV-2 pneumonia in Wuhan, China: a single-centered, retrospective, observational study. Lancet Respir Med 2020;8:475-481.

24) Dweck MR, Bularga A, Hahn RT, Bing R, Lee KK, Chapman AR, White A, Salvo GD, Sade LE, Pearce K, Newby DE, Popescu BA, Donal E, Cosyns B, Edvardsen T, Mills NL, Haugaa K. Global evaluation of echocardiography in patients with COVID-19. Eur Heart J Cardiovasc Imaging 2020 Jun 18;jeaa178. doi: 10.1093/ehjci/jeaa178

25) Pagnesi M, Baldetti L, Beneduce A, Calvo F, Gramegna M, Pazzanese V, Ingallina G, Napolano A, Finazzi R, Ruggeri A, Ajello S, Melisurgo G, Camici PG, Scarpellini P, Tresoldi M, Landoni G, Ciceri F, Scandroglio AM, Agricola E, Cappelletti AM. Pulmonary hypertension and right ventricular involvement in hospitalised patients with COVID-19. Heart. 2020 Sep;106(17):1324-1331. doi: 10.1136/heartjnl-2020-317355.

26) Huang L, Zhao P, Tang D, Zhu T, Han R, Zhan C, Liu W, Zeng H, Tao Q, Xia L. Cardiac Involvement in Patients Recovered From COVID-2019 Identified Using Magnetic Resonance Imaging. JACC Cardiovasc Imaging. 2020 May 12:S1936-878X(20)30403-4. doi: 10.1016/j.jcmg.2020.05.004.

27) Knight DS, Kotecha T, Razvi Y, Chacko L, Brown JT, Jeetley PS, Goldring J, Jacobs M, Lamb LE, Negus R, Wolff A, Moon JC, Xue H, Kellman P, Patel N, Fontana M COVID-19: Myocardial injury in survivors.. Circulation. 2020 Jul 14. doi: 10.1161/CIRCULATIONAHA.120.049252

28) Puntmann VO, Carerj ML, Wieters I, Fahim M, Arendt C, Hoffmann J, Shchendrygina A, Escher F, VasaNicotera M, Zeiher AM, Vehreschild M, Nagel E. Outcomes of Cardiovascular Magnetic Resonance Imaging in Patients Recently Recovered From Coronavirus Disease 2019 (COVID-19). JAMA Cardiol. 2020 Jul 27:e203557

29) Rali AS, Ranka S, Shah Z, Sauer AJ. Mechanisms of Myocardial Injury in Coronavirus Disease 2019.Card Fail Rev. 2020 May 25;6:e15. doi: 10.15420/cfr.2020.10.

30) Lang JP, Wang X, Moura FA, Siddiqi HK, Morrow DA, Bohula EA. A current review of COVID-19 for the cardiovascular specialist. Am Heart J. 2020 Aug;226:29-44. doi: 10.1016/j.ahj.2020.04.025 
31) Bavishi C, Bonow RO, Trivedi V, Abbott JD, Messerli FH, Bhatt DL. Acute myocardial injury in patients hospitalized with COVID-19 infection: A review.Prog Cardiovasc Dis. 2020 Jun 6:S0033-0620(20)30123-7. doi: 10.1016/j.pcad.2020.05.013

32) Sandoval Y, Januzzi JL Jr, Jaffe AS. Cardiac Troponin for the Diagnosis and Risk-Stratification of Myocardial Injury in COVID-19: JACC Review Topic of the Week.J Am Coll Cardiol. 2020 Jul 3:S07351097(20)35888-5. doi: 10.1016/j.jacc.2020.06.068.

33) Wong CY, O'Moore-Sullivan T, Leano R, Byrne N, Beller E, Marwick TH. Alterations of left ventricular myocardial characteristics associated with obesity. Circulation. 2004 Nov 9;110(19):3081-7

34) Turkbey EB, McClelland RL, Kronmal RA, Burke GL, Bild DE, Tracy RP, Arai AE, Lima JA, Bluemke DA. The impact of obesity on the left ventricle: the Multi-Ethnic Study of Atherosclerosis (MESA). JACC Cardiovasc Imaging. 2010 Mar;3(3):266-74.

35) Dorbala S, Crugnale S, Yang D, Di Carli MF. Effect of body mass index on left ventricular cavity size and ejection fraction.Am J Cardiol. 2006 Mar 1;97(5):725-9.

36) Mangner N, Scheuermann K, Winzer E, Wagner I, Hoellriegel R, Sandri M, Zimmer M, Mende M, Linke A, Kiess W, Schuler G, Körner A, Erbs S. Childhood obesity: impact on cardiac geometry and function.JACC Cardiovasc Imaging. 2014 Dec;7(12):1198-205

37) Lavie CJ, Alpert MA, Arena R, Mehra MR, Milani RV, Ventura HO. Impact of obesity and the obesity paradox on prevalence and prognosis in heart failure.JACC Heart Fail. 2013 Apr;1(2):93-102.

38) Lee HJ, Kim HL, Lim WH, Seo JB, Kim SH, Zo JH, Kim MA. Subclinical alterations in left ventricular structure and function according to obesity and metabolic health status.PLoS One. 2019 Sep 12;14(9):e0222118.

39) Russo C, Sera F, Jin Z, Palmieri V, Homma S, Rundek T, Elkind MS, Sacco RL, Di Tullio MR. Abdominal adiposity, general obesity, and subclinical systolic dysfunction in the elderly: A population-based cohort study.Eur J Heart Fail. 2016 May;18(5):537-44.

40) Dini FL, Fabiani I, Miccoli M, Galeotti GG, Pugliese NR, D'Agostino A, Scartabelli A, Conte L, Salvetti G, Santini F, Pedrinelli R. Prevalence and determinants of left ventricular diastolic dysfunction in obese subjects and the role of left ventricular global longitudinal strain and mass normalized to height.Echocardiography. 2018 Aug;35(8):1124-1131

41) Chirinos JA, Sardana M, Satija V, Gillebert TC, De Buyzere ML, Chahwala J, De Bacquer D, Segers $P$, Rietzschel ER; Asklepios investigators. Effect of Obesity on Left Atrial Strain in Persons Aged 35-55 Years (The Asklepios Study). Am J Cardiol. 2019 Mar 1;123(5):854-861

42) Sasson Z, Rasooly Y, Gupta R, Rasooly I. Left atrial enlargement in healthy obese: prevalence and relation to left ventricular mass and diastolic function.Can J Cardiol. 1996 Mar;12(3):257-63.

43) Kenchaiah S, Evans JC, Levy D, Wilson PW, Benjamin EJ, Larson MG, Kannel WB, Vasan RS. Obesity and the risk of heart failure.N Engl J Med. 2002 Aug 1;347(5):305-13

44) Wang TJ, Parise H, Levy D, D'Agostino RB Sr, Wolf PA, Vasan RS, Benjamin EJ. Obesity and the risk of newonset atrial fibrillation. JAMA. 2004 Nov 24;292(20):2471-7.

45) Murphy NF, Maclntyre K, Stewart S, Hart CL, Hole D, McMurray JJ. Long-term cardiovascular consequences of obesity: 20-year follow-up of more than 15000 middle-aged men and women (the Renfrew-Paisley study).Eur Heart J. 2006 Jan;27(1):96-106.

46) Alpert MA, Agrawal H, Aggarwal K, Kumar SA, Kumar A. Heart failure and obesity in adults: pathophysiology, clinical manifestations and management. Curr Heart Fail Rep. 2014 Jun;11(2):156-65.

47) Anderson FA Jr, Spencer FA. Risk factors for venous thromboembolism. Circulation. 2003 Jun 17;107(23 Suppl 1):19-16 
48) Shah RV, Murthy VL, Abbasi SA, Eng J, Wu C, Ouyang P, Kwong RY, Goldfine A, Bluemke DA, Lima J, JeroschHerold M. Weight loss and progressive left ventricular remodelling: The Multi-Ethnic Study of Atherosclerosis (MESA).Eur J Prev Cardiol. 2015 Nov;22(11):1408-18.

49) Piché ME, Poirier P, Lemieux I, Després JP. Overview of Epidemiology and Contribution of Obesity and Body Fat Distribution to Cardiovascular Disease: An Update. Prog Cardiovasc Dis. 2018 Jul-Aug;61(2):103-113

50) Lee CM, Huxley RR, Wildman RP, Woodward M. Indices of abdominal obesity are better discriminators of cardiovascular risk factors than BMI: a meta-analysis. J Clin Epidemiol. 2008 Jul;61(7):646-53.

51) Nicklas BJ, Cesari M, Penninx BW, Kritchevsky SB, Ding J, Newman A, Kitzman DW, Kanaya AM, Pahor M, Harris TB. Abdominal obesity is an independent risk factor for chronic heart failure in older people.J Am Geriatr Soc. 2006 Mar;54(3):413-20.

52) Emerging Risk Factors Collaboration, Wormser D, Kaptoge $S$, Di Angelantonio E, Wood AM, Pennells L, Thompson A, Sarwar N, Kizer JR, Lawlor DA, Nordestgaard BG, Ridker P, Salomaa V, Stevens J, Woodward M, Sattar N, Collins R, Thompson SG, Whitlock G, Danesh J. Separate and combined associations of body-mass index and abdominal adiposity with cardiovascular disease: collaborative analysis of 58 prospective studies Lancet. 2011 Mar 26;377(9771):1085-95

53) Ingraham NE, Barakat AG, Reilkoff R, Bezdicek T, Schacker T, Chipman JG, Tignanelli CJ, Puskarich MA. Understanding the renin-angiotensin-aldosterone-SARS-CoV axis: a comprehensive review.Eur Respir J. 2020 Jul 9;56(1):2000912. doi: 10.1183/13993003.00912-2020.

54) NAIMARK A, CHERNIACK RM. Compliance of the respiratory system and its components in health and obesity. J Appl Physiol. 1960 May;15:377-82

55) Yap JC, Watson RA, Gilbey S, Pride NB. Effects of posture on respiratory mechanics in obesity.J Appl Physiol (1985). 1995 Oct;79(4):1199-205.

56) Sharp JT, Druz WS, Kondragunta VR. Diaphragmatic responses to body position changes in obese patients with obstructive sleep apnea.Am Rev Respir Dis. 1986 Jan;133(1):32-7.

57) Lin CK, Lin CC. Work of breathing and respiratory drive in obesity. Respirology. 2012 Apr;17(3):402-11.

58) Sampson MG, Grassino AE. Load compensation in obese patients during quiet tidal breathing. J Appl Physiol Respir Environ Exerc Physiol. 1983 Oct;55(4):1269-76

59) Ochs-Balcom HM, Grant BJ, Muti P, Sempos CT, Freudenheim JL, Trevisan M, Cassano PA, lacoviello L, Schünemann HJ. Pulmonary function and abdominal adiposity in the general population.Chest. 2006 Apr;129(4):853-62.

60) Wise RA, Enright PL, Connett JE, Anthonisen NR, Kanner RE, Lindgren P, O'Hara P, Owens GR, Rand CS, Tashkin DP. Effect of weight gain on pulmonary function after smoking cessation in the Lung Health Study.Am J Respir Crit Care Med. 1998 Mar;157(3 Pt 1):866-72

61) Ferretti A, Giampiccolo P, Cavalli A, Milic-Emili J, Tantucci C. Expiratory flow limitation and orthopnea in massively obese subjects. Chest. 2001 May;119(5):1401-8

62) Rossi A, Polese G, Brandi G, Conti G. Intrinsic positive end-expiratory pressure (PEEPi).Intensive Care Med. 1995 Jun;21(6):522-36

63) Kelly TM, Jensen RL, Elliott CG, Crapo RO. Maximum respiratory pressures in morbidly obese subjects.Respiration. 1988;54(2):73-7.

64) da Rosa GJ, Schivinski Cl. Assessment of respiratory muscle strength in children according to the classification of body mass index. Rev Paul Pediatr. 2014 Jun;32(2):250-5.

65) Hurewitz AN, Susskind $\mathrm{H}$, Harold WH. Obesity alters regional ventilation in lateral decubitus position.. J Appl Physiol (1985). 1985 Sep;59(3):774-83. 
66) Vaughan RW, Cork RC, Hollander D. The effect of massive weight loss on arterial oxygenation and pulmonary function tests.Anesthesiology. $1981 \mathrm{Apr} ; 54(4): 325-8$

67) Littleton SW, Tulaimat A. The effects of obesity on lung volumes and oxygenation. Respir Med. 2017 Mar;124:15-20

68) Poulain M, Doucet M, Major GC, Drapeau V, Sériès F, Boulet LP, Tremblay A, Maltais F. The effect of obesity on chronic respiratory diseases: pathophysiology and therapeutic strategies. CMAJ. 2006 Apr 25;174(9):1293-9

69) Gopalakrishnan P, Tak T. Obstructive sleep apnea and cardiovascular disease.Cardiol Rev. 2011 NovDec;19(6):279-90

70) Masa JF, Pépin JL, Borel JC, Mokhlesi B, Murphy PB, Sánchez-Quiroga MÁ. Obesity hypoventilation syndrome.Eur Respir Rev. 2019 Mar 14;28(151):180097.

71) Wang Y, Tikellis C, Thomas MC, Golledge J. Angiotensin converting enzyme 2 and atherosclerosis. Atherosclerosis. 2013 Jan;226(1):3-8

72) Motta-Santos D, Santos RAS, Santos SHS. Angiotensin-(1-7) and Obesity: Role on cardiorespiratory fitness and COVID-19 implications.Obesity (Silver Spring). 2020 Jul 4:10.1002/oby.22949

73) Santos RA, Ferreira AJ, Verano-Braga T, Bader M. Angiotensin-converting enzyme 2, angiotensin-(1-7) and Mas: new players of the renin-angiotensin system.J Endocrinol. 2013 Jan 18;216(2):R1-R17.

74) Magalhaes GS, Rodrigues-Machado MDG, Motta-Santos D, Campagnole-Santos MJ, Santos RAS. Activation of Ang-(1-7)/Mas Receptor Is a Possible Strategy to Treat Coronavirus (SARS-CoV-2) Infection. Front Physiol. 2020 Jun 19;11:730.

75) Kruglikov I.L., Schere P.E. The role of adipocytes and adipocyte-like cells in the severity of COVID-19 infections [published online ahead of print April 27, 2020] https://doi.org/10.1002/oby.22856 Obesity (Silver Spring)

76) Fabian Sanchis-Gomar, Carl J. Lavie, Mandeep R. Mehra, Brandon Michael Henry, Giuseppe Lippi. Obesity and Outcomes in COVID-19: When an Epidemic and Pandemic Collide.Mayo Clin Proc. 2020 Jul; 95(7): 1445-1453.

77) Kassir R. Risk of COVID-19 for patients with obesity. Obes Rev. 2020 Jun;21(6):e13034.

78) Sattar N, McInnes IB, McMurray JJV.Sattar N, et al. Obesity a Risk Factor for Severe COVID-19 Infection: Multiple Potential Mechanisms. Circulation. 2020 Apr 22.

79) Considine RV, Sinha MK, Heiman ML, Kriauciunas A, Stephens TW, Nyce MR, Ohannesian JP, Marco CC, McKee $L$, Bauer TL, et al. Serum immunoreactive-leptin concentrations in normal-weight and obese humans. $\mathrm{N}$ Engl J Med. 1996 Feb 1;334(5):292-5.

80) Finucane FM, Davenport C. Coronavirus and Obesity: Could Insulin Resistance Mediate the Severity of Covid-19 Infection?Front Public Health. 2020 May 12;8:184.

81) Chen G, Wu D, Guo W, Cao Y, Huang D, Wang H, Wang T, Zhang X, Chen H, Yu H, Zhang X, Zhang M, Wu S, Song J, Chen T, Han M, Li S, Luo X, Zhao J, Ning Q.Chen G, et al. Clinical and immunological features of severe and moderate coronavirus disease 2019. J Clin Invest. 2020 Apr 13:137244

82) Chen T, Wu D, Chen H, Yan W, Yang D, Chen G, Ma K, Xu D, Yu H, Wang H, Wang T, Guo W, Chen J, Ding C, Zhang X, Huang J, Han M, Li S, Luo X, Zhao J, Ning Q. Clinical characteristics of 113 deceased patients with coronavirus disease 2019: retrospective study. BMJ. 2020 Mar 26;368:m1091

83) Dugail I, Amri EZ, Vitale N. High prevalence for obesity in severe COVID-19: Possible links and perspectives towards patient stratification. Biochimie. $2020 \mathrm{Jul}$ 7:S0300-9084(20)30155-3 
84) SHARP JT, HENRY JP, SWEANY SK, MEADOWS WR, PIETRAS RJ. THE TOTAL WORK OF BREATHING IN NORMAL AND OBESE MEN. J Clin Invest. 1964 Apr;43(4):728-39.

85) Moammar MQ, Azam HM, Blamoun Al, Rashid AO, Ismail M, Khan MA, DeBari VA. Alveolar-arterial oxygen gradient, pneumonia severity index and outcomes in patients hospitalized with community acquired pneumonia.Clin Exp Pharmacol Physiol. 2008 Sep;35(9):1032-7.

86) Goldhaber SZ, Grodstein F, Stampfer MJ, Manson JE, Colditz GA, Speizer FE, Willett WC, Hennekens CH. A prospective study of risk factors for pulmonary embolism in women.JAMA. 1997 Feb 26;277(8):642-5.

87) Bompard F, Monnier H, Saab I, Tordjman M, Abdoul H, Fournier L, Sanchez O, Lorut C, Chassagnon G, Revel MP. Pulmonary embolism in patients with Covid-19 pneumonia. Eur Respir J. 2020 May 12:2001365.

88) Pfeffer MA, Shah AM, Borlaug BA. Heart Failure With Preserved Ejection Fraction In Perspective. Circ Res. 2019 May 24;124(11):1598-1617.

89) Stefanini GG, Chiarito M, Ferrante G, Cannata F, Azzolini E, Viggiani G, De Marco A, Briani M, Bocciolone M, Bragato R, Corrada E, Gasparini GL, Marconi M, Monti L, Pagnotta PA, Panico C, Pini D, Regazzoli D, My I, Kallikourdis M, Ciccarelli M, Badalamenti S, Aghemo A, Reimers B, Condorelli G; Humanitas COVID-19 Task Force. Early detection of elevated cardiac biomarkers to optimise riskstratification in patients with COVID-19.Heart. 2020 Aug 14:heartjnl-2020-317322. doi: 10.1136/heartjnl2020-317322

90) Mahajan K, Chand Negi P, Ganju N, Asotra S. Cardiac biomarker-based risk stratification algorithm in patients with severe COVID-19.Diabetes Metab Syndr. 2020 Jun 18;14(5):929-931. doi:

10.1016/j.dsx.2020.06.027

91) Ball L, Pelosi P. How I ventilate an obese patient. Crit Care. 2019 May 16;23(1):176.

92) Imber DA, Pirrone M, Zhang C, Fisher DF, Kacmarek RM, Berra L. Respiratory Management of Perioperative Obese Patients. Respir Care. 2016 Dec;61(12):1681-1692

93) Maclntyre NR. Physiologic Effects of Noninvasive Ventilation. Respir Care. 2019 Jun;64(6):617-62894) Petrof BJ. Diaphragm Weakness in the Critically III: Basic Mechanisms Reveal Therapeutic Opportunities.Chest. 2018 Dec;154(6):1395-1403.

95) Mayo P, Volpicelli G, Lerolle N, Schreiber A, Doelken P, Vieillard-Baron A. Ultrasonography evaluation during the weaning process: the heart, the diaphragm, the pleura and the lung. Intensive Care Med. 2016 Jul;42(7):1107-17.

96) Matamis D, Soilemezi E, Tsagourias M, Akoumianaki E, Dimassi S, Boroli F, Richard JC, Brochard L. Sonographic evaluation of the diaphragm in critically ill patients. Technique and clinical applications. Intensive Care Med. 2013 May;39(5):801-10

97) Esteban A, Anzueto A, Frutos F, Alía I, Brochard L, Stewart TE, Benito S, Epstein SK, Apezteguía C, Nightingale P, Arroliga AC, Tobin MJ; Mechanical Ventilation International Study Group. Characteristics and outcomes in adult patients receiving mechanical ventilation: a 28-day international study. JAMA. 2002 Jan $16 ; 287(3): 345-55$.

98) Torres A, Gatell JM, Aznar E, el-Ebiary M, Puig de la Bellacasa J, González J, Ferrer M, Rodriguez-Roisin R. Re-intubation increases the risk of nosocomial pneumonia in patients needing mechanical ventilation.Am J Respir Crit Care Med. 1995 Jul;152(1):137-41.

99) Vivier E, Mekontso Dessap A, Dimassi S, Vargas F, Lyazidi A, Thille AW, Brochard L. Diaphragm ultrasonography to estimate the work of breathing during non-invasive ventilation.Intensive Care Med. 2012 May;38(5):796-803

100) Tuinman PR, Jonkman AH, Dres M, Shi ZH, Goligher EC, Goffi A, de Korte C, Demoule A, Heunks L. Respiratory muscle ultrasonography: methodology, basic and advanced principles and clinical applications in ICU and ED patients-a narrative review. Version 2. Intensive Care Med. 2020 Apr;46(4):594-605 
101) Vignon P. Ventricular diastolic abnormalities in the critically ill. Curr Opin Crit Care. 2013 Jun;19(3):242-9

102) Jha AK. Left ventricular diastolic dysfunction as a predictor of weaning failure from mechanical ventilation.Intensive Care Med. 2020 Jun 2

103) de Meirelles Almeida CA, Nedel WL, Morais VD, Boniatti MM, de Almeida-Filho OC. Diastolic dysfunction as a predictor of weaning failure: A systematic review and meta-analysis. J Crit Care. 2016 Aug;34:135-41.

104) Vignon P. Ventricular diastolic abnormalities in the critically ill. Curr Opin Crit Care. 2013 Jun;19(3):242-9

105) Liu J, Shen F, Teboul JL, Anguel N, Beurton A, Bezaz N, Richard C, Monnet X. Cardiac dysfunction induced by weaning from mechanical ventilation: incidence, risk factors, and effects of fluid removal.Crit Care. 2016 Nov 12;20(1):369.

106) Hurford WE, Favorito F. Association of myocardial ischemia with failure to wean from mechanical ventilation.Crit Care Med. 1995 Sep;23(9):1475-80

107) Lemaire F, Teboul JL, Cinotti L, Giotto G, Abrouk F, Steg G, Macquin-Mavier I, Zapol WM. Acute left ventricular dysfunction during unsuccessful weaning from mechanical ventilation.Anesthesiology. 1988 Aug;69(2):171-9.

108) Gobel FL, Norstrom LA, Nelson RR, Jorgensen CR, Wang Y. The rate-pressure product as an index of myocardial oxygen consumption during exercise in patients with angina pectoris. Circulation. 1978 Mar;57(3):549-56.

109) Stefanini GG, Montorfano M, Trabattoni D, Andreini D, Ferrante G, Ancona M, Metra M, Curello S, Maffeo D, Pero G, Cacucci M, Assanelli E, Bellini B, Russo F, lelasi A, Tespili M, Danzi GB, Vandoni P, Bollati M, Barbieri L, Oreglia J, Lettieri C, Cremonesi A, Carugo S, Reimers B, Condorelli G, Chieffo A. ST-Elevation Myocardial Infarction in Patients With COVID-19: Clinical and Angiographic Outcomes. Circulation. 2020 Jun 23;141(25):2113-2116.

110) Chatila W, Ani S, Guaglianone D, Jacob B, Amoateng-Adjepong $Y$, Manthous CA. Cardiac ischemia during weaning from mechanical ventilation. Chest. 1996 Jun;109(6):1577-83

111) Mekontso-Dessap A, de Prost N, Girou E, Braconnier F, Lemaire F, Brun-Buisson C, Brochard L. B-type natriuretic peptide and weaning from mechanical ventilation.Intensive Care Med. 2006 Oct;32(10):1529-36.

112) Teboul JL, Abrouk F, Lemaire F. Right ventricular function in COPD patients during weaning from mechanical ventilation.Intensive Care Med. 1988;14 Suppl 2:483-5 